\title{
Alimentation végétale et systèmes de production en Limousin, du Néolithique à la Renaissance
}

\section{Anne Bouchette}

\section{QpenEdition Journals}

Édition électronique

URL : http://journals.openedition.org/adlfi/7256

ISSN : 2114-0502

Éditeur

Ministère de la culture

Référence électronique

Anne Bouchette, «Alimentation végétale et systèmes de production en Limousin, du Néolithique à la Renaissance », ADLFI. Archéologie de la France - Informations [En ligne], Limousin, mis en ligne le 01 mars 2007, consulté le 03 mai 2019. URL : http://journals.openedition.org/adlfi/7256

Ce document a été généré automatiquement le 3 mai 2019.

(C) Ministère de la Culture et de la Communication, CNRS 


\title{
Alimentation végétale et systèmes de production en Limousin, du Néolithique à la Renaissance
}

\author{
Anne Bouchette
}

Identifiant de l'opération archéologique : 2754

Date de l'opération : 2007 (PC)

Inventeur(s) : Bouchette Anne (BEN)

1 Initié en 2006, le PCR sur "L'Alimentation végétale et les systèmes de production en Limousin du Néolithique à la Renaissance » a pour objectif de développer les études archéobotaniques et de proposer, à terme, une synthèse régionale. En effet, l'exploitation et la gestion des ressources naturelles est une préoccupation primordiale des sociétés rurales, les plantes occupant une place essentielle dans la vie quotidienne, l'économie et l'environnement. Les principaux thèmes développés dans le cadre de ce projet de recherche portent donc sur les productions végétales, qu'elles soient locales ou allochtones, leurs traitements, leurs modes de conservation et leurs utilisations. Par leur fonction, les structures de stockage constituent également un élément pilier à prendre en considération puisqu'elles vont interférer sur le traitement des récoltes.

2 Les actions réalisées en 2007 se sont inscrites dans la continuité du travail amorcé en 2006. Plusieurs d'entre elles ont été poursuivies, comme l'inventaire des prélèvements restant à tamiser des fouilles préventives et programmées et les notices de fouilles relatives aux analyses paléoenvironnementales achevées ou en cours de réalisation.

Plusieurs analyses anthracologiques et carpologiques ont été également effectuées ou sont en cours. Pour les premières, les sites concernés sont :

et, pour les secondes :

$5 \quad$ Les périodes chronologiques ayant bénéficié de ces analyses sont la fin du premier âge du Fer, avec les sites de Parsac et de Peyrat-de-Bellac, l'époque gallo-romaine avec ceux de 
Saint-Gence et de Bugeat et le Moyen Âge pour tous les autres sites, à l'exception de celui de Lalo, vraisemblablement Temps Modernes.

6 À la suite de ce travail, une première synthèse des données carpologiques des plantes cultivées et alimentaires du Moyen Âge a été ébauchée (A. Bouchette, I. Figueiral). Treize sites, soit dix-sept occupations, ont été pris en considération. Leur répartition sur le territoire limousin est très inégale, puisque $65 \%$ d'entre eux sont localisés en HauteVienne et $35 \%$ en Corrèze. Plus de cinquante plantes cultivées et alimentaires rendent compte des pratiques culturales et alimentaires de cette période.

7 Riche d'une cinquantaine de sites protohistoriques, gallo-romains et médiévaux, la base de données anthracologiques est également en cours d'élaboration (P. Poirier). Elle comprend, à ce jour, 35 taxons dont plusieurs essences de plantes cultivées à des fins alimentaires, comme le châtaignier, le noyer et la vigne. Plusieurs sites, en cours d'analyse, devraient compléter le corpus permettant l'élaboration d'une synthèse régionale en relation avec la thématique du PCR.

8 La base de données xylologiques et dendrologiques est constituée actuellement de quatre sites d'époque protohistorique, gallo-romaine et médiévale. Elle est formée à la fois de collections de bois naturels et de bois travaillés (copeaux, objets manufacturés) (Fig. ${ }^{\circ} 1$ : Écuelle de Malemort, la Renaudie et de Saint-Gence). Diachroniques, ces sites fournissent des jalons pour une approche paléoenvironnementale, éthnobotanique et économique en Limousin. En 2008, ils devraient être enrichis de l'étude de deux nouvelles collections des bois gorgés d'eau du second âge du Fer et d'époque gallo-romaine : celles de la Gagnerie et du Bourg à Saint-Gence (Haute-Vienne, fouille G. Lintz).

9 La constitution d'une base de données palynologique est également projetée, mais a dû être reportée à 2008 (M.-F. Diot, P. Guenet, Y. Miras).

Les résultats de deux datations ${ }^{14} \mathrm{C}$ des prélèvements des sites du Château de Comborn à Orgnac-sur-Vézère (Corrèze) et du Puy de l'Eglise à Saint-Julien-aux-Bois (Corrèze), sollicitées auprès du centre de datation par le radiocarbone de l'université Claude Bernard à Lyon 1, dans le cadre du programme Artemis, ont été également obtenus. Pour le premier site, la datation est de 782 à 981 apr. J.-C. [(Lyon -4107) Âge ${ }^{14}$ C BP : $1140 \pm 30$ ], pour le second, de 352 à 111 av. J.-C. [(Lyon -4108) Âge ${ }^{14} \mathrm{C} \mathrm{BP} \mathrm{:} 2155 \pm 30$ ]. Elles permettent de mieux dater deux couches de céréales mises en évidence sur ces sites, la première déjà analysée (PCR 2006), la seconde, en cours d'étude.

11 Parmi les autres axes de travail privilégiés, un corpus photographique des plantes cultivées est en cours d'élaboration à partir du jardin médiéval de Dignac (Charente M. Botineau). Il permettra d'illustrer les différentes espèces mises au jour dans les contextes archéologiques, autrement que sous forme de fruits et de graines (Fig. $\mathrm{n}^{\circ} 2$ : Céréales : engrain, épautre et orge vêtue).

Parallèlement à la constitution de ces différentes bases de données, plusieurs publications de sites archéologiques contenant des données paléoenvironnementales ont été réalisées. D'autres sont en projet. Parmi les perspectives 2008, toutes les actions en cours seront poursuivies dans la mesure des disponibilités de chacun. Un nouvel axe de recherche a également été envisagé. Il porte sur les structures de stockage pour les périodes pour lesquelles il existe des données carpologiques disponibles en quantité suffisante, c'est-àdire l'époque protohistorique (J.-M. Beausoleil), la période gallo-romaine (A. Besombes) et le Moyen Âge (P. Conte). 
ANNEXES

Fig. $\mathrm{n}^{\circ} 1$ : Écuelle de Malemort, la Renaudie et de Saint-Gence
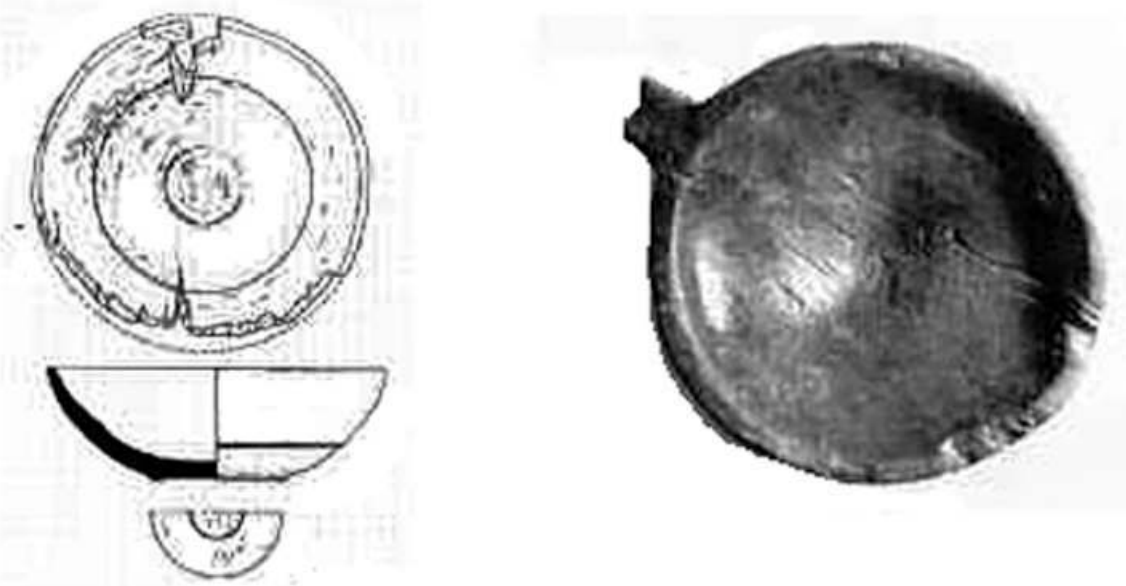

Auteur(s) : Mille, P. (dessin) ; Lintz, G. Crédits : Mille, P. et Lintz, G (2007)

Fig. $n^{\circ} 2$ : Céréales : engrain, épautre et orge vêtue
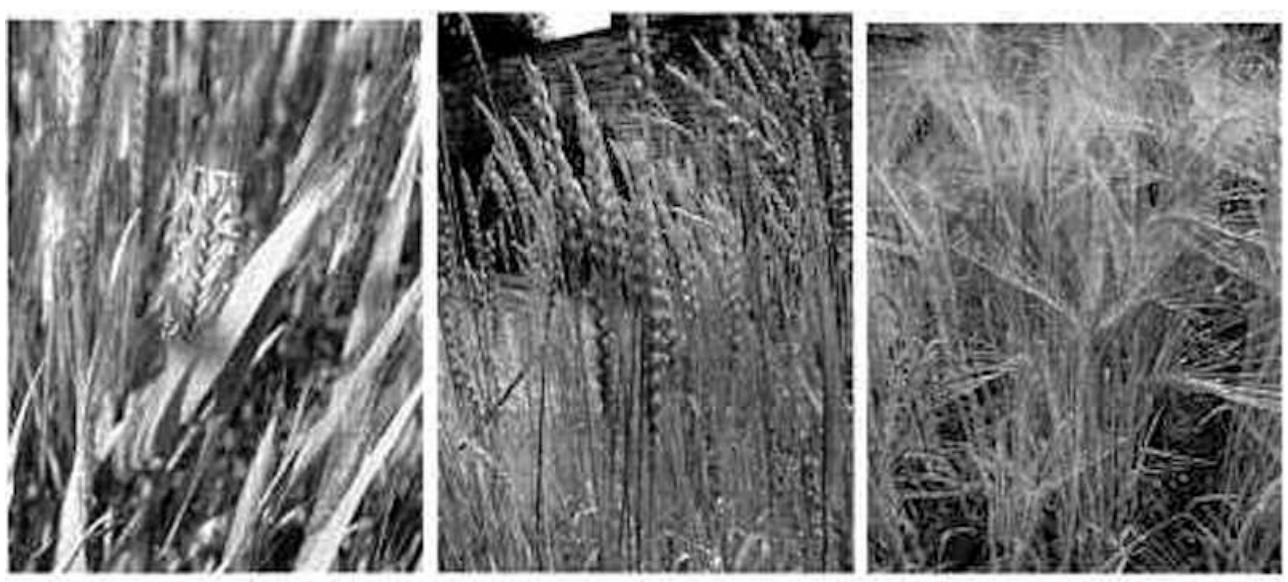

Auteur(s) : Botineau, M. Crédits : Botineau, M (2007) 
INDEX

operation Projet collectif de recherche (PCR)

Index chronologique : âge du Fer, Empire romain, Moyen Âge, Néolithique, Renaissance, Temps Modernes

Index géographique : Limousin, Creuse (23), Corrèze (19), Haute-Vienne (87), Parsac, Bugeat, Limoges

\section{AUTEURS}

ANNE BOUCHETTE

BEN 